\title{
Study Upon the Invertebrates with Economic Importance for the Vegetables Cultures in the Guşterița Ecological Garden (Sibiu County)
}

Iuliana ANTONIE

"Lucian Blaga" University, Sibiu, Romania, iuliana_antonie@yahoo.com

Mirela STANCIU CĂRĂTUŞ

"Lucian Blaga" University, Sibiu, Romania mirela_stanciu2008@yahoo.com

Maria TĂNASE

"Lucian Blaga" University, Sibiu, Romania maritanase@yahoo.com

Petronela PAVEL

"Lucian Blaga" University, Sibiu, Romania pavel.petronela@yahoo.com

Monica GĂUREANU

National Agency for Animal Breeding "prof.dr.G.K.Constantinescu",

Brăila Office, Romania

moro6769@yahoo.com

\begin{abstract}
The fortified church in Guşteritg got its final shape during the $16^{\text {th }}$ century. During more recent times it became a leisure park and then a vegetable garden named "The Prioress Garden". Nowadays there is developing an agricultural-educational experiment having an original character. The main idea of the experiment is the educational one in the idea of knowing the practice of an agriculture based on ecological concepts and also adding the concept of the biodynamic. The specific aims are: identifying the general measures of prevention and reduction of the attack of the pests and finding ways in order to maintaining the population of the invertebrates under the pest limit. The evaluation and classification of the invertebrates/insects was done in accordance with their food. The specific methods applied in the field were: the observation upon the elements of the biocoenocis, collecting of the biological material directly from the plants. In the lab, on the base of the determinatives there were identified the beneficial and pest invertebrates fauna. The result of the researches emphasizes that a biological, modern and profitable gardening is based on the living component in the cultivated ecosystems which reduces the pest populations, proving the beneficial role for the man.
\end{abstract}

Keywords: invertebrates, ecological agriculture 


\section{INTRODUCTION}

The fortified church in Guşteriţa was built during the $13^{\text {th }}$ century having the form of a Romanic basilica. During the time, due to the attacks of the Tatars, Turks and others, the inhabitants added defensive constructions, fortifications and wide inner walls. The shape of a fortress church was definitive during the $16^{\text {th }}$ century. The wide inner court within the walls was transformed in more recent times in a leisure park and then in a vegetables garden, named, suggestively "The Prioress Garden". Nowadays here is developing an agro touristy educational experiment having an original character.

The Evangelic - Lutheran Parish in Sibiu founded at the fortified church in Gusterita an educational centre for environment and young people. Sibiu Parish is certified in the community system EMAS (Environmental Management Systems). EMAS is defined by the Minister of Environment, Water and Forests as "a system of an operational management of environment, which leads to a continuous improvement of the performances of environment at the level of the best available techniques of the moment as well as with the improvement of the economic performances".

Within the centre the stress is on reduction of the electricity and fuel consumption, the use of regenerable energies, recycling the scraps, adequate urban mobility and on ecologically produced food. All these have as a goal the protection of the environment. Within this context there was reestablished "The Prioress Garden" as the first school of non-formal education.

In nowadays is practiced a coming back in the past regarding the agricultural practice to which are added the new concepts like biodiversity, the use of natural factors and the elimination of any alien element in practice, sustainability, durability and education of the population regarding the understanding and practice of a ecological agriculture. An important element, among others is knowing the beneficial and pest fauna; the use of beneficial one in restraining the pest fauna and the total elimination of the chemical materials in order to remove the animal or vegetal pests.

The study aims the following specific goals: the identification of the general measures of prevention and reduction of the pest attack in the Guşteriţa ecological garden; giving the ways regarding the maintaining of the population of pest invertebrates under the pest limit; the evaluation of the invertebrates in accordance to their food.

\section{MATERIAL AND METHOD}

I. The time during the investigation was done: 2014 - 2015;

II. The locality where the investigation was done: Guşteriţa (Sibiu County);

III. Special methods applied in the field:

- The direct observation upon the elements of the biocoenosis; 
- The method of direct collecting, which is a qualitative one and allow us a more thorough analysis regarding the relation between host plant and phytophagous insect or between the latter and other beneficial species in the biocenoesis;

- The application of warning measures against the pests attacks, taking into account the concept from 2005 emphasized by Badea and his coworkers in the work "Guide of traditional and ecological practices in the ecological vegetable gardening" the fact that in the biologic gardens the pests are kept under control by intensification and application of prevention methods. The authors underline that these "have to be used intensively, and the protective and fortifying preparations must have priority". As a result of our research we identified the culture technology applied in Guşteriţa Garden and established that this adjusted on this methodology of the traditional and ecological works accepted by the ecological agriculture. In this respect, the general measures of prevention or reduction of the attack of the pests in the ecological garden Gusteriţa are as follows:

1. The use of adequate tools for the work of the soil: the hoe for the roads, the grubbing hoe for planting.

2. In the researched agro ecosystem, a fast method of enriching the soil in humus is used "green fertilizer" made of Sinapis alba L. (white mustard), Brassica rapa L. (rape) and Avena sativa L. (oats). For this the plants are mowed and then are left for some days to dry and then are incorporated into the soil at a depth of $15 \mathrm{~cm}$. In the solar is used Galinsoga parviflora (Asteraceae).

3. A mix named "mulch" is considered by many farmers the "ointment of the soil". This operation may be considered like pre compost. This has as an effect the enrichment of the soil with nitrogen. For this operation was used a mix of horse dung with sawdust. The stratum measured some centimeters.

4. In October 2014 took place the action of autumn compost. This operation lasts for 12 months and finally was obtained good quality compost, well decomposed. The great part of the compost comes from own resources: sawdust, saw grass, leaves from the orchards, corn cob, bean stalk to which is added dung (from horse and cow). In order to obtain a quality compost is used the Klickitat Kounty Program "Compost Mix Calculator", which identifies the components of the compost and the ratio among them. The decomposed compost was spread on the soil and after that was incorporated. It is a natural fertilizer of extreme importance both for the soil and the plants.

5. For increasing the biologic activity of the soil in the Guşteriţa ecological garden, this was aspersed with sting nettle leaven. There was also used a mix of garlic with onion against the coleopteron Phyllotreta atra F. (black flea) that attacked the radish culture.

6. The seeds used in Guşteriţa garden were acquired from Eco ruralis Association in Cluj Napoca and Agrosem International Alba Iulia that produce seeds in ecological conditions.

7. In the future, in order to reduce the attack of the pests is considered also the crop rotation. 
8. Using the allelopathy guide, there were done the most adequate associations of plants both in the garden and solar.

9. The cultures are associated and cultivated under the shape of concentric ribbons. The goal of these measures is to prevent or to reduce the attack of the pests as well as to favor the biologic activity of the soil and to diminish the weeds. This thing was taken from nature where plants don't grow in monocultures.

10. Among the beneficial weeds kept among the cultivated plants are: the dandelion, the clover and the spontaneous leguminous plants. The pests, such as horse radish, Senecto vulgaris L., and road-weed are greatly taken away because they represent the host for the pests. There is used the shovel (without turning the stratum), eliminating the rhizome.

11. There is used the foul water because is rich in bacteria. This is put into the soil at the temperature of the environment.

12. The culture hygiene is an important measure of prevention or reduction of the attack of the pests. In this respect the dry vegetal material is chopped and the sawdust is used for compost.

III. Specific methods applied in the lab comprise the unpacking operations of the samples, labeling, numbering and determining. For the last operation were used the determinants: Panin (1951), Teodorescu \& Antonie (2008); Harde \& Severa (1988); Koch (1992), Năstăsescu \& col. (2007). For the raw sorting of the biologic material we used the magnifying glass IOR 1983, and for determination and photos the magnifying glass IPM Scope.

\section{RESULTS AND DISCUTIONS}

Another purpose of the ecologic agriculture is to know and to protect the beneficial fauna (prey and saprophagous). As a result of the direct observations there was identified a part of the beneficial fauna belonging to the researched agro system (Table 1).

Table 1: The beneficial fauna with economical importance identified on the base of the observations and direct collecting from the plants in the agro system Gușterița

\begin{tabular}{|l|c|l|}
\hline \multicolumn{1}{|c|}{ Taxon } & Trophic base & \multicolumn{1}{c|}{ Observations } \\
\hline $\begin{array}{l}\text { Subkingdom Arthropoda } \\
\text { Class Arachnida } \\
\text { Order Araneae }\end{array}$ & aphids & $\begin{array}{l}\text { Attack against eggs, larva } \\
\text { and adult stadium }\end{array}$ \\
\hline
\end{tabular}




\begin{tabular}{|c|c|c|}
\hline $\begin{array}{l}\text { Class Chilopoda } \\
\text { Family Lithobiidae } \\
\text { Lithobius forficatus L. }\end{array}$ & $\begin{array}{l}\text { insects, worms and } \\
\text { small reptiles }\end{array}$ & $\begin{array}{l}\text { Attack against egg, larva } \\
\text { and adult stadium of the } \\
\text { insects }\end{array}$ \\
\hline $\begin{array}{l}\text { Family Geophilidae } \\
\text { Geophilus flavus De Geer }\end{array}$ & insects & $\begin{array}{l}\text { Attack against eggs and } \\
\text { larva stadium }\end{array}$ \\
\hline $\begin{array}{l}\text { Class Diplopoda } \\
\text { Family Julidae } \\
\text { Chromatoiulus unilineatus } \\
\text { Koch. }\end{array}$ & saprophaguos & $\begin{array}{l}\text { They have an important } \\
\text { role in decomposing the } \\
\text { vegetal remains and } \\
\text { putting back into the } \\
\text { circuit of some } \\
\text { substances. }\end{array}$ \\
\hline \multirow{2}{*}{$\begin{array}{l}\text { Class Insecta } \\
\text { Family Dermaptrea } \\
\text { Forficula auricularia L. }\end{array}$} & aphids, moths & $\begin{array}{c}\text { Attack against eggs and } \\
\text { larva stadium } \\
\end{array}$ \\
\hline & $\begin{array}{l}\text { acaridae belonging to } \\
\text { family Tetranychidae. }\end{array}$ & Adults \\
\hline \multirow{2}{*}{$\begin{array}{l}\text { Family Coccinelidae } \\
\text { Coccinella septempunctata } \\
\text { L. }\end{array}$} & aphids & $\begin{array}{l}\text { Attack against eggs, larva } \\
\text { and adult stadium }\end{array}$ \\
\hline & $\begin{array}{l}\text { acaridae belonging to } \\
\text { family Tetranychidae. }\end{array}$ & Adults \\
\hline $\begin{array}{l}\text { Family Cantharidae } \\
\text { Cantharis obscura L. }\end{array}$ & aphids & $\begin{array}{l}\text { Attack against eggs, larva } \\
\text { and adult stadium }\end{array}$ \\
\hline $\begin{array}{l}\text { Family Carabidae } \\
\text { Carabus gigas Creutzer }\end{array}$ & $\begin{array}{l}\text { other invertebrates, } \\
\text { especially insects }\end{array}$ & $\begin{array}{l}\text { Attack against eggs, larva } \\
\text { and adult stadium }\end{array}$ \\
\hline
\end{tabular}

In the Guşteriţa vegetable garden there identified 4 classes of invertebrates (Arachnida, Chilopoda, Diplopoda, Insecta) belonging to 8 families (Araneae, Lithobiidae, Geophilidae, Julidae, Dermaptrea, Coccinelidae, Cantharidae, Carabidae) and 6 zoophagous species (Lithobius forficatus L., Geophilus flavus De Geer, Forficula auricularia L., Coccinella septempunctata L, Cantharis obscura L., Carabus gigas Creutzer) and a saprophaguos one (Chromatoiulus unilineatus Koch.). These are beneficial species and play an important economic role in a good functioning of the agro ecosystem. Their presence in a great number confirms the fact that in this ecosystem the technology of an ecologic culture is respected.

If in the nature each group of invertebrates, each species plays an important role in the good functioning of the ecosystem, from a human point of view, which stress the man's interests, there are pest species for the cultures that can produce important damages having major economic effects because they feed with cultivated vegetables. During our study there were identified pest that had produced damages in the researched biotope (Table 2) 
Table 2: The pest invertebrates with economic importance identified on the base of the observations and direct collecting from the plants in the Guşteriţa agro ecosystem

\begin{tabular}{|c|c|c|}
\hline Taxon & Trophic base & Observations \\
\hline $\begin{array}{l}\text { Class Insecta } \\
\text { Order Homoptera } \\
\text { Family Aphididae } \\
\text { Brevicoryne brassicae L. }\end{array}$ & $\begin{array}{l}\text { Attack the plants } \\
\text { belonging to Brassicaceae } \\
\text { family: cabbage, radish, } \\
\text { cauliflower, mustard, } \\
\text { turnip cabbage, rape }\end{array}$ & $\begin{array}{l}\text { Pest in the larva and } \\
\text { adult stadium. }\end{array}$ \\
\hline $\begin{array}{l}\text { Order Heteroptera } \\
\text { Family Pentatomidae } \\
\text { Euryderma ornatum L. }\end{array}$ & $\begin{array}{l}\text { Attack the cabbage, } \\
\text { cauliflower, rape, mustard, } \\
\text { and radish. }\end{array}$ & $\begin{array}{l}\text { Pest in the larva and } \\
\text { adult stadium. }\end{array}$ \\
\hline $\begin{array}{l}\text { Order Coleoptera } \\
\text { Family Curculionidae } \\
\text { Baris laticollis Marsh. }\end{array}$ & $\begin{array}{l}\text { Attack the cabbage and the } \\
\text { cauliflower }\end{array}$ & $\begin{array}{l}\text { Pest in the larva and } \\
\text { adult stadium. }\end{array}$ \\
\hline $\begin{array}{l}\text { Family Chrysomelidae } \\
\text { Phyllotreta atra F. }\end{array}$ & $\begin{array}{l}\text { Pest specific for the plants } \\
\text { Brassicaceae family. }\end{array}$ & Attack as an adult. \\
\hline $\begin{array}{l}\text { Family Scarabeidae } \\
\text { Melolontha melolontha L. }\end{array}$ & Strawberry, herb plants & $\begin{array}{l}\text { Attack in olygopod } \\
\text { larva stadium but } \\
\text { also as an adult } \\
\end{array}$ \\
\hline $\begin{array}{l}\text { Order Lepidoptera } \\
\text { Family Noctuidae } \\
\text { Mamestra brassicae L. }\end{array}$ & $\begin{array}{l}\text { Polyphagous pest attacks } \\
\text { cabbage, cauliflower, } \\
\text { turnip cabbage, mustard }\end{array}$ & $\begin{array}{l}\text { Attack in polypod } \\
\text { larva stadium }\end{array}$ \\
\hline $\begin{array}{l}\text { Family Pieridae } \\
\text { Pieris brasicae L. }\end{array}$ & $\begin{array}{l}\text { Attack cabbage, } \\
\text { cauliflower, horse radish }\end{array}$ & $\begin{array}{l}\text { Attack in polypod } \\
\text { larva stadium. }\end{array}$ \\
\hline
\end{tabular}

The pests with economic importance observed and collected in the Guşteriţa vegetable garden belong to class Insecta. There were identified 4 orders of insects (Homoptera, Heteroptera, Coleoptera, Lepidoptera), 7 families (Aphididae, Pentatomidae, Curculionidae, Chrysomelidae, Scarabeidae, Noctuidae, Pieridae). There were identified a number of 7 pest species (Brevicoryne brassicae L., Euryderma ornatum L., Baris laticollis Marsh., Phyllotreta atra F., Melolontha melolontha L., Mamestra brassicae L., Pieris brasicae L.) but damages had been produced only by 4 (Brevicoryne brassicae L., Phyllotreta atra F., Mamestra brassicae L., Pieris brasicae L.).

\section{CONCLUSION}

In a healthy garden there must be created favorable conditions of habitat in order to attract the beneficial organisms and to keep them there for a longer time. We mention the necessity that the system must have its own, independent life in which the fauna to be subjected to the auto regulation both from the quality and quantity point of view. The farmer must be attentive that these mechanisms of auto regulation to function, they being a natural break against the uncontrolled proliferation of the pests. 
The ratio between the beneficial and pest fauna are to be set naturally, so the existence of a limited number of pests not to worry the farmer. We must understand that in this biologic equilibrium the beneficial fauna multiplies only if there is plenty of food. We underline that in the same time with multiplication of the pest of the plant there will proliferate the number of its preys and saprophagous.

Knowing the ratio between the beneficial and pest fauna in the researched agro system has economic, social effects as well as effects upon the environment:

- Monitoring the invertebrates offer data regarding the quality and duration of life. Our researches demonstrated that where the ecologic principles are respected the indicators of the soil quality grow and as a result there will be obtained bigger harvests (economic effects); these invertebrates belong to the classes Arachnida, Chilopoda, Diplopoda and Insecta.

- A correct management of the beneficial invertebrates determines the lower of the pest invertebrates belonging to the insecta orders Homoptera, Coleoptera, Lepidoptera. Maintaining the pests under the pest limit leads to a bigger productions and diminishes the costs for the main food products (social effect);

- Knowing the rules that govern the researched agro system allows the selection the optimum method of keeping the equilibrium among the invertebrate species and the application of the methods and measures of a proper biologic control in order to maintain the health of the ecosystem on the base of the eco sangenesis principles with beneficial effect upon the environment.

\section{REFERENCES}

Badea, R., Ștefănescu, S.L., Dumitrașcu, M. (2005), Îndrumar de practici tradiționale și ecologice în legumicultura ecologică , București, Ed. Estfalia.

Harde, K.W., \& Severa, F., (1988). Der Kosmos-Kaferfuhrer, die mitteleuropaischen Kafer, Stuttgart, Franckh'sche Verlagschandlung.

Koch, K., (1992). Bodenökologie interdisziplinär, Berlin, Springer-Verlag Heidelberg.

Năstăsescu, M., Teodorescu, D., Stavrescu-Bedivan, M.M., Aioanei, F. (2007). Zoologia nevertebratelor. Manual de lucrari practice, București, Edit. Universitatii din Bucuresti.

Panin, S. (1951). Determinatorul coleopterelor dăunătoare şi folositoare din Republica Populară Română, București, Ed. de Stat pentru Literatură Științifică si Didactica.

Teodorescu, I., Antonie Vlad, I., (2008). Entomologie, Bucuresti, Ed. Geea, http://www.mmediu.ro/beta/domenii/emas/ 